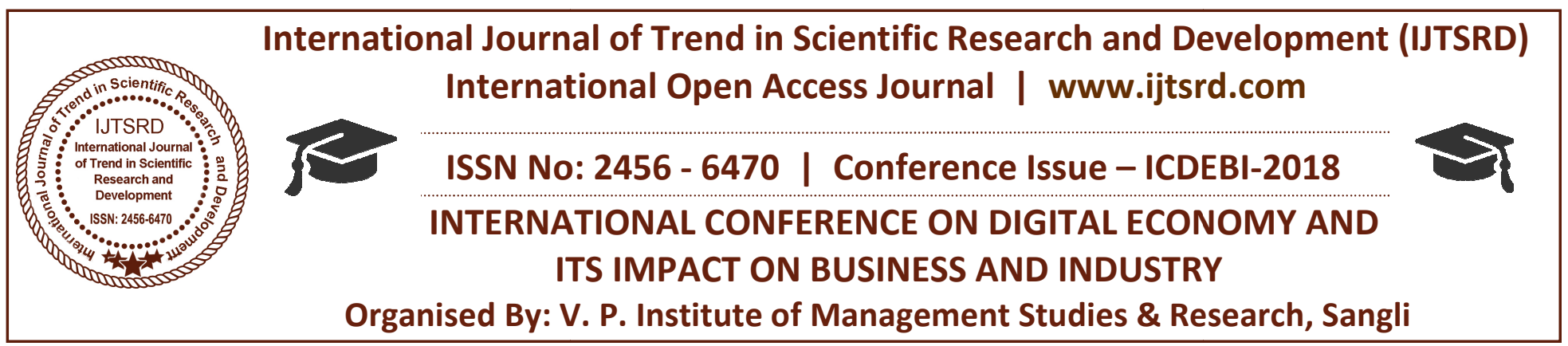

\title{
Digitalisation in Rural Entrepreneurship a Paradigm Shift
}

\author{
Prof. Hiremath Uday V. \\ Sangli, Maharashtra, India
}

\section{ABSTRACT}

This study aims to fill that fissure by studying how a digitalization occurring in rural entrepreneurship. This organizing issue is challenging, because stakeholders of rural entrepreneurs are not governed by any formal authority. To answer that question, it accepts forms of organizing as a theoretical view, which provides structure to examine organizing issues. In today, rural entrepreneurship considerably impacts many issues, including economic development, employment, food supply and social security. With increasing numbers of people moving from rural to urban areas due to poor employment opportunities, and the complexity of running their own businesses, the problem of potential social unrest, amongst others, becomes more credible. It is therefore crucial that researchers, particularly in those countries with large rural populations, investigate this problem and provide ways of solving it. Such challenges facing entrepreneurship in remote or rural places require modern, innovative business leaders, skilful political thinkers, and greater numbers of trained professionals, and academics who can think dynamically, and bring their ideas into broader societal use. In most practical cases, individuals who conduct their businesses in rural areas do so by utili sing locally available resources. Their business activities improve the standard of living for local communities by creating employment opportunities for people living in proximate villages and provide sources of entrepreneurial activity to establish industrial and business units in this rural sector of the economy. Similarly, rural entrepreneurship can further be described in terms of rural industrial is at ion. The existence of rural entrepreneurship which leads to viable economies in rural areas is therefore of extreme importance. Regardless of the extent to which rural entrepreneurs engage in a variety of activities, which range far beyond simply agriculture, they are still not fully Indus try alisedin their thinking and approach, due to the number of challenges that confront them in rural regions worldwide

Keywords: Rural entrepreneurship, Employment opportunities, Industrial is at ion, Challenges in digitalization etc.

\section{INTRODUCTION}

India, which was considered as primarily an agricultural economy, is developing at a very fast rate. It has now become a knowledge economy. It has got the world's largest pool of scientists, doctors, engineers and experts in every field. Till few years back India's metros were developed this had all the latest technologies. The evolution of information and communication technologies (ICTs) revolution in India has created a technological divide between the urban areas and rural areas many of India's companies and well educated enjoy the benefits of ICTs, these technologies were not accessible or affordable for the majority of the population. The divide is exacerbated by the deeply ingrained disparities of gender and social class, which determine who can or cannot use technology. Despite recent Liberalization, Privatization and Globalization since the 1990, accessibility is also hindered by language barriers, and a lack of suitable content and applications in local languages. The economic impact of digitalization of rural India is far and wide. To quote in the words of Kane J. Shore a Journalist "What a difference five years can make. In that time, a project to bring the Information Age to villagers in southern India has given 50,000 "information shop" users in a dozen" information shop" users in a dozen communities high- 
speed wireless telephone and Internet access. It has also helped improve more traditional Indian communication methods, such as public loudspeaker networks and community newspapers."

India lives in its villages, declared M. K. Gandhi at the beginning of 20th century. "If the facilities available in the cities are not made available to rural population, the Governments will not have done their duties" said by Dr. A. P. J. Abdul Kalam, Former President of India. The life in Indian villages is simple and isolated; although they are connected now a day with cell phones and digital television transmission, yet they are cut off from the main stream of urban areas due to poor road connectivity and market for their agricultural commodities. The health, educational and civil facilities are also either absent or not up to the mark. Making such villages as 'Smart Village' is surely a noble program announced by Government. But no one in villages has seen what exactly, in the Indian conditions, smart village means. The objective of this paper is to discuss about components of Digital India and its nine pillars, adaption of 'look at Villages' policy and the smart villages driving towards smart India and the prerequisites of a smart villages cluster.

\section{Concept of Digital India:}

The vision of Digital India program is inclusive growth in areas of electronic services, products, manufacturing and job opportunities etc. and it is centered on three key areas - Digital Infrastructure as a Utility to Every Citizen, Governance \& Services on Demand and Digital Empowerment of Citizens.

Bharat Broadband Network Limited acts as the initial milestone of the program, which executes the National Optical Fiber Network project and also the custodian of Digital India (DI) project. Bharat Broadband Network Limited (BBNL) had ordered United Telecoms Limited to connect 250,000 villages through broadband, and planning to create 28,000 sets of BPOs in various states and set up at least one Common Service Centre in each of the gram panchayats in the state. These are the initial steps of Digital India expected to be completed by 2017 . The 2016 Union budget of India announced with 11 technology initiatives including the use data analytics to nab tax evaders, creating a substantial opportunity for IT companies to build out the systems that will be required. Digital Literacy mission will cover six crore rural households. It is also planned to connect 550 farmer markets in the country through the use of technology. These are the points that the Government of India hopes to achieve growth on multiple fronts with the Digital India Program. The government aims to target 'Nine Pillars of Digital India' as follows:

A. Broadband Highways

B. Universal Access to Mobile Connectivity

C. Public Internet Access Programme

D. e-Governance - Reforming Government through Technology

E. e-Kranti - Electronic delivery of services

F. Information for All

G. Electronics Manufacturing

H. Digital or IT for Jobs

I. Early Harvest Programmes

\section{Impact of digitalization:}

The customers are exploring the new buying experience. Bene fits of this technological innovation. Customers are becoming leaders with the evolution of digitization. The ultimate goal of any company is to provide better user experience. A top-notch user experience is the best way to engage the customers. Differentiated experience will increase customer loyalty and improves feedback. With the initiation of digitization, customers are influencing the market ecosystem by analyzing the products/services. They are exploring the new buyer experience with online transactions, shopping etc. This era is called as "Information Age" as customers are becoming particular about the knowledge on product/service. Before the purchase, customers are reviewing the product with research. With digitization, it became easier to provide information to the customers. Through digitization economic benefits are being captured. Consider a simple case of E-ticketing services. The Digitization has made it simpler and convenient to book your tickets just by logging into the respected websites. You will receive confirmation Mail/SMS after the payment process. The websites are optimized for easy navigation and easy payment facilities. No need of waiting at queues or contacting agents for tickets. You can easily book your tickets by sitting at home.

\section{Economic impact of digitalization on rural area:}

It increases in employment opportunities. The foremost benefit of digitalization is increase in employment opportunities in rural areas. Large number of small entrepreneurs has got employment in provision of Internet in rural areas. The second benefit 
is the improvement in standard of living of the people by improving their income. Large numbers of people are getting benefitted by these facilities. They are using internet services and other facilities provided by various schemes like lifelines India and are getting awareness regarding various plant diseases, new methods of farming etc. They are also getting information on various diseases of farm animals and methods by which they can remain healthy and their output also increases.

Rural community is making full use of available techniques and is reducing risk and uncertainty by getting market information online. Fishermen are checking weather conditions before venturing into the sea. They are also carrying mobile phones with them so that in case of any emergencies they can contact their relatives or authorities and they can get help. Large number of rural youth is getting training in using computers, MS Office and Internet. Internet Kiosks are conducting educational and training programs for rural youth. Under various programs large number of rural youth is being trained through village knowledge centers. Rural people have become aware of importance of spoken English, since English is the main language required for Internet.

\section{Frame of Rural entrepreneurship:}

Business working in rural environments cut off from primary metropolitan sites can be defined as part of rural entrepreneurship, and such enterprises function under extremely complex and turbulent business conditions presented by remote and underdeveloped areas, where local production is primarily committed to subsistence farming. Primary concepts in entrepreneurial practice involve independence, innovation, decision-making, forecasting, implementation and achieving success. However, rural entrepreneurship needs to be better developed to improve its broader economic participation. A transformation in how rural entrepreneurship is practiced could attract greater business success, but effective economic activities can only be achieved by the digitalisation of rural entrepreneurship. Digitalisation can be described in terms of the infrastructural processes associated with digital technologies, in which analogue information is transcribed to digital form and applied in broader social and institutional contexts. Rural areas are perceived to be entirely different from intensively settled urban and suburban areas, and are also distinct from natural landscapes or wilderness, such as forests or mountains. Rural enterprises can benefit from the use of local resources and can produce products or services to meet local demands, since they are able to access cheap labour from within their communities. Although it is acknowledged that no single, unified and accepted definition for the term 'entrepreneurship' exists, it is one dimension of strategic posture, which encompasses the risk-taking tendency of businesses, their ability to compete aggressively, their proactive initiatives and their product innovations, which are all entrepreneurial activities, and which indicates that all manner of organisations therefore behave entrepreneur like. Rural entrepreneurship implies the emergence or establishment of entrepreneurial activities in rural areas; in other words, the establishment of industries; which also implies that rural entrepreneurship is synonymous with rural industrialisation. Rural entrepreneurship represents the informal sector of the economy, characterised by small-scale businesses, including small traders and artisans. Rural entrepreneurship can be considered an important solution for reducing poverty, minimising rural-urban migration, addressing economic disparities and alleviating unemployment in developing rural and underdeveloped areas. Rural entrepreneurship presents a major opportunity for those who instead migrate from rural to semi-urban or urban areas and most rural entrepreneurs are faced with the multiple problems presented by the unavailability of primary amenities in these areas of developing countries. Due to this exodus of skills, a lack of educated individuals, financial limitations and insufficient technical and conceptual abilities, together make it difficult for rural entrepreneurs to success-fully establish locally based industries. In most practical cases, individuals who conduct their businesses in rural areas do so by utilising locally available resources. Their business activities improve the standard of living for local communities by creating employment opportunities for people living in proximate villages and provide sources of entrepreneurial activity to establish industrial and business units in this rural sector of the economy. Similarly, rural entrepreneurship can further be described in terms of rural industrialisation.

The existence of rural entrepreneurship which leads to viable economies in rural areas is therefore of extreme importance. Regardless of the extent to which rural entrepreneurs engage in a variety of activities, which range far beyond simply agriculture, they are still not fully industrialised in their thinking and approach, due 
to the number of challenges that confront them in rural regions worldwide. The challenges lead to the success of ambitious start-ups remaining low, with factors such as market sizes, government policies and geographical profiles are continuing to influence their long-term performance. There is ostensibly little difference between rural and urban enterprises in terms of their structure, of how such businesses are organised and managed, and of how the characteristics of individual entrepreneurs are exhibited. Thus, it would appear that there is no specific category for, or definition of, rural entrepreneurs, beyond being individuals who manage business ventures in rural settings.

\section{The magnitude of rural entrepreneurship digitalisation}

The digitalisation of rural entrepreneurship is of tremendously important for the development and competitiveness of rural businesses. Digitalisation is a highly effective strategic growth strategy for businesses in emerging markets of the word, and there is much evidence that, in many countries, the improvement of entrepreneurial activities is regarded as a strategy to boost national productivity and job creation, which also improves their economic independence. Entrepreneurial actions strengthen personal and collective capabilities amongst local communities, and SMEs are currently regarded as mechanisms for economic growth and equitable development in creating labour intensive, capitalsaving initiatives that ensure the creation of many new jobs. Small-scale businesses play a survival role for poorer households in the development of selfconfidence, business and other skills, and the socioeconomic encourage the women. Small businesses provide employment opportunities for rural communities, specifically by minimising migration of rural populations to urban areas, improving standards of living for local communities and promoting rural tourism-related art activities. Enterprise and entrepreneurship are the drivers of economic growth in rural, which indicate that the ongoing challenges facing traditional rural sectors, and the future success of rural economies, are inextricably linked to the capacity rural entrepreneurs, possess to innovate and identify new business opportunities that create jobs and income in these areas. Entrepreneurial development in the form of rural SMMEs has also emerged as a strong agent for socio-economic diversification. Small enterprises are not only important in contributing to local economies, but, from an international perspective, play a vital role in the creation of national marketplace employment which is amongst the largest in the world, is likewise largely supported by SMMEs, and the advanced technology employed in both China and India has assisted in industrialising their vast rural areas and allowed national penetration into widely diverse international markets.

\section{Pros and Cons of rural entrepreneurship digitalization:}

Pros:

1. Diminish the business costs.

2. Give strength to home-grown entrepreneurs.

3. Right of entry to world markets.

4. Speeding up the manufacturing enterprise.

5. Marketing connections.

6. Improved business transactions.

7. Wider distribution of customer service improvements.

\section{Cons:}

1. Sky-scraping setting up costs.

2. Technologically advanced skills are required.

3. Not have of safe cyber security.

4. Lack of privacy and data protection laws.

The cost benefits and importance of digitalisation of rural entrepreneurship must be clearly understood and be encouraged as this will be an important promotional tool for strengthening company brand. The concept of digitalisation will improve and bring new changing trends in emerging markets including rural industries and scale up product development and product diversification, as well as promoting idea generation through use of social media.

\section{Conclusion:}

It concludes that due to the various challenges such as lack of broadband availability and electricity in many rural places, there is a lot of improvements need to be done to improve rural business of rural communities as well. It has been found that rural entrepreneurs are also faced with barriers including poor telecommunications infrastructure, management incompetence, lack of marketing skills and insufficient entrepreneurial knowledge, therefore, it is suggested that to government and private sector should be encouraged to work together to improve coordination and its policy development for the rural places. National governments should establish steering agencies responsible for championing and 
iodinating rural entrepreneurial digitalisation and modern technologies networking systems for rural communities.

\section{REFERENCES:}

1. http://indianexpress.com/article/technology/technews-technology/projects-and-policies-launchedat-digital-india-week

2. https://en.wikipedia.org/wiki/Government_of_Indi a

3. Bharat Broadband Network Limited, retrieved from http://www.bbnl.nic.in/index1.aspx?1sid=18 $\&$ lev $=1 \&$ lid $=18 \&$ langid $=1$

4. http://tech.firstpost.com/news-analysis/indiasfantastic-broadband-project-that-you-shouldknow-about-81871.html

5. http://economictimes.com/tech/ites/budget-2016technology-initiatives-to-boost-digital-indiadrive/articleshow/51194047.cms
6. The Times Of India, Posted on 18th feb'16, Retrieved from http://timesofindia.indiatimes.com/india/Governm ent-aims-to-give-Digital-India-benefits-tofarmers-PM-Modi/articleshow/51046765.cms

7. Digital India: Governance Transformation Kindle Edition by K S Nippani, B K MUrthy, Vitasta Publishing Pvt Ltd .

8. Sriyani, G. T. W. 2010b. Human Capital and its Impact on Small Firm Success [Online]. Available at:

http://repository.kln.ac.lk/handle/123456789/7141

9. Rivas L T S, Cano M G, Austria F M M. Need for Developing Human Capital Management in SMEs [Online]. 2013. Available at: http://eujournal.org/index.php/esj/article/viewFile/ $1249 / 1258$

10. Tulus T. Entrepreneurship development: SMEs in Indonesia. Journal of Developmental Entrepreneurship. 2007;12(01):95-118 